\title{
19. Einsatz gentechnologischer Methoden in der Impfstoffentwicklung gegen das SARS-CoV-2-Virus
}

„Dear world, we have a vaccine!" twitterte Prof. Florian Krammer (Icahn School of Medicine at Mount Sinai, New York, USA) am 09.11.2020.

Im Dezember 2019 wurden Fälle von Lungenentzündung mit unbekannter Krankheitsursache in der Stadt Wuhan, China, gemeldet. Der verursachende Erreger, identifiziert als das Beta-Coronavirus SARS-CoV-2, ist eng mit SARS-CoV verwandt, das für den Ausbruch von SARS zwischen 2002 und 2004 verantwortlich war (Zhou et al., 2020). SARSCoV-2 steht für „Severe Acute Respiratory Syndrome Corona Virus 2“ (schweres akutes Atemwegssyndrom Corona Virus 2). Das neue Virus SARS-CoV-2 verursachte im Dezember 2019 eine große Epidemie in China, breitete sich dann global aus und wurde im März 2020 von der Weltgesundheitsorganisation (WHO) zur Pandemie erklärt (zu einer seuchengeschichtlichen Einordnung der Covid-19-Pandemie siehe Fangerau/Labisch, Kap. 20).

\subsection{Die ersten Schritte in der Grundlagenforschung}

Zunächst zu den Viren selbst: Coronaviren sind von einer Lipidschicht (Fettschicht) umhüllte Viren mit einem einzelsträngigen, positiv-sinnigen RNA-Genom statt einer 
doppelsträngigen DNA. ${ }^{1}$ Vier solcher Coronaviren - zwei Alpha-Coronaviren (NL63 und 229E) und zwei Beta-Coronaviren (HKU1 und OC43) - zirkulieren beim Menschen schon seit vielen Jahren und verursachen Erkältungskrankheiten (Cui et al., 2019). Alle vier dieser Viren sind vermutlich zoonotischen Ursprungs, gelangen also vom Tier zum Menschen und sind dann so mutiert, dass sie auch von Mensch zu Mensch übertragen werden können. Die OC43-Beta-Coranavirus-Variante wird als möglicher Erreger der „Russischen Grippe“ von 1889 bis 1890 diskutiert. Diese Möglichkeit wurde durch eine phylogenetische, d. h. die genetische Abstammung der Viren betreffende, Analyse nahegelegt, die ergab, dass sich OC43 und das bovine Coronavirus ( $\mathrm{BCOV}$ ) von einem gemeinsamen Vorfahren um 1890 abspalteten. Darüber hinaus wurden SARS-CoV und das Middle Eastern Coronavirus des Mittleren Ostens (MERS-CoV) ebenfalls als Zoonose identifiziert und lösten Epidemien mit hoher Sterblichkeitsrate beim Menschen aus (Cui et al., 2019).

Vor der Covid-19-Pandemie wurden keine Impfstoffe gegen Coronaviren für den Einsatz beim Menschen zugelassen. Ihre Entwicklung wurde bis zu diesem Zeitpunkt nur mit niedriger Priorität verfolgt, da die beim Menschen zirkulierenden Coronaviren relativ milde Erkrankungen verursachten bzw. durch nicht ganz geklärte Umstände MERS-CoV und SARS-CoV keine weltweiten Pandemien auslösten und sich, abgesehen von lokalen Ausbrüchen, verflüchtigten. Entsprechend wurde die Entwicklung von Impfstoffen gegen humane Coronaviren zunächst nicht weiterverfolgt.

Allerdings gab es durchaus Anläufe beim SARS-Ausbruch 2002, der dann 2004 endete, Impfstoffe gegen SARS-CoV zu entwickeln. Zwei dieser Impfstoffe gelangten in präklinische Phase-I-Studien (Martin et al., 2008). Jedoch wurde die Entwicklung gestoppt, da das Virus in der menschlichen Bevölkerung ausgerottet wurde und seit 2004 nicht wieder aufgetreten war. Impfstoffe gegen MERS-CoV werden derzeit aktiv entwickelt

1 RNA (Ribonukleinsäurse) ist eine Nukleinsäure, besteht aber im Gegensatz zur doppelsträngigen DNA (Desoxyribonukleinsäure) aus einem Einzelstrang und besitzt als Rückgrat zwischen den Basen kein Desoxyribose, sondern einfach nur Ribose. Die DNA enthält die Erbinformationen von Lebewesen. Die Funktion der mRNA im menschlichen Körper ist die Umsetzung von genetischer Information der DNA in Proteine. mRNA steht für „messenger RNA“ - also „Boten-RNA“, die vom Kern in den Rest der Zelle wandert, aber niemals zurück in den Kern. Vereinfacht ausgedrückt: Die DNA ist beim Menschen das permanente Speichermedium für die genetische Information, die RNA dient als Zwischenspeicher und Überträger von Informationen. Sie ist deutlich instabiler als DNA. Von einem positiven Sinn (,sense“) der einzelsträngigen RNA spricht man, wenn diese direkt als Vorlage zur Synthese von Proteinen genutzt werden kann. Sie entspricht damit der Leserichtung der mRNA. Bei einem negativen Sinn (,antisense“) muss die RNA vor der Proteinsynthese in positivsinnige RNA umgeschrieben werden. 
und wurden von der Coalition for Epidemic Preparedness Innovations (CEPI), der Koalition für Innovationen in der Epidemievorbeugung, unterstützt.

Durch präklinische Studien von Impfstoffen gegen SARS-CoV und MERS-CoV wurde früh erkannt, dass man als entscheidendes Angriffsziel (Antigen) für CoronavirusImpfstoffe das sogenannte Spike-Protein des Virus nutzen könnte. Dies war von großer Bedeutung für die schnelle Entwicklung von SARS-CoV-2-Impfstoffen im Jahre 2020 und zeigt, wie wichtig Grundlagenforschung auch für die anwendungsbezogene Forschung ist, denn ohne dieses Wissen hätte die aktuelle Impfstoffentwicklung deutlich länger gebraucht. So aber wusste man bereits, dass die meisten Coronaviren nur ein großes Oberflächenprotein, eben dieses Spike-Protein, kodieren, welches für die Rezeptorbindung und die Membranfusion ${ }^{2}$ mit menschlichen Zellen verantwortlich ist (Tortorici/ Veesler, 2019). Im Fall von SARS-CoV-2 (und SARS-CoV) bindet das Spike-Protein zur Kontaktaufnahme mit der Zelle an das Angiotensin-konvertierende Enzym 2 (ACE2), einen Rezeptor auf Wirtszellen im Nasen-Rachen-Raum und Lungengewebe. Dort wird es dann in das Zellinnere aufgenommen, indem sich Vesikel von der Membran abschnüren und in das Innere der Zelle wandern (Hoffmann et al., 2020). Diesem Schritt folgt die Verschmelzung der viralen und endosomalen Membranen, woran sich dann die Freisetzung des viralen Genoms in das Zytoplasma anschließt. Antikörper, die an das Spike-Protein binden, insbesondere an seine rezeptorbindende Domäne (RBD, „receptor-binding domain“), verhindern die Bindung an das ACE2 auf der Wirtszelle und neutralisieren das Virus. Auf der Grundlage dieses Wissens wurde das Spike-Protein als antigenes Ziel für die Entwicklung eines Impfstoffs gegen SARS-CoV-2 identifiziert.

Seit dem Ausbruch der COVID-19-Pandemie haben Grundlagenforscher viel gelernt über die Immunantwort auf SARS-CoV-2 nach natürlicher Infektion. Diese Erkenntnisse haben die anfänglichen Annahmen bekräftigt, dass das Spike-Protein eine entscheidende Angriffsstelle für die Impfstoffentwicklung ist. Für Antikörper, die gegen das Spike-Protein gerichtet sind - sowohl solche, die auf die RBD, als auch solche, die auf andere Regionen des Proteins abzielen - konnte bereits frühzeitig belegt werden, dass das Virus so unschädlich gemacht (neutralisiert) werden kann (u. a. Alsoussi et al., 2020; Amanat et al., 2020; Liu et al., 2020; Okba et al., 2020). Obwohl die Stärke der Antikörperreaktion auf das Spike-Protein sehr unterschiedlich ist, ähneln die bisher bekannt gewordenen Immunreaktionen bislang zudem einer typischen Antikörperreaktion

2 Um in Zellen eindringen zu können, müssen Viren zunächst Kontakt mit den Zellen aufnehmen, was im Falle von SARS-CoV-2 über bestimmte Oberflächenproteine (Rezeptoren) geschieht, die dann eine Reaktion der Zelle auslösen. In einem zweiten Schritt muss die RNA ins Innere der Zelle eindringen, was durch Endozytose geschieht. Danach muss die Fettschicht, die das Virus umgibt, mit der Membran der Endosomen verschmelzen. Diesen Vorgang nennt man auch Membranfusion. 
auf ein respiratorisches Virus: So erfolgt anfänglich ein durch Plasmablasten (Zellen des Immunsystems, die der Produktion und Sekretion von Antikörpern dienen) hervorgerufener Anstieg von Antikörpern, der wiederum gefolgt wird von einem leichten Rückgang und einer möglichen Stabilisierung auf einem Ausgangswert durch langlebige Plasmazellen. Schleimhaut-Antikörper-Reaktionen werden auch durch natürliche Infektionen beim Menschen ausgelöst. Darüber hinaus wurde außerdem gezeigt, dass das Spike-Protein auch CD4+ T-Zellen aktiviert, das sind sogenannte T-Killer-Zellen, die Körperzellen eliminieren, die Viruspartikel auf ihrer Oberfläche präsentieren. Auf der anderen Seite werden während einer natürlichen Infektion mit SARS-CoV-2 weniger CD8+ T-Zellen (T-Helferzellen) angeregt, was sich langfristig auf die Nachhaltigkeit der Impfstoffe auswirken könnte (Grifoni et al., 2020).

Aus tierexperimentellen Untersuchungen, die (auch rechtlich) zwingend erforderlich sind, bevor Impfstoffe am Menschen getestet werden dürfen, hat sich bei nichtmenschlichen Primaten („non-human primates“, NHPs) gezeigt, dass eine Infektion mit SARS-CoV-2 vor einer erneuten Infektion schützt (u. a. Deng et al., 2020). Impfexperimente an NHPs zeigten, dass neutralisierende Antikörper, aber nicht T-Zell-Reaktionen, mit dem Schutz korrelierten. Neutralisierende Antikörper gibt es im menschlichen Körper in verschiedenen Typen und Verteilungen. Eine natürliche Infektion kann sowohl mukosale (zur Schleimhaut gehörende) ${ }^{3}$ Antikörperreaktionen (sekretorisches Immunglobulin A, IgA) und systemische, vor allem im Blutkreislauf verteilte Antikörperreaktionen vom Typ IgG hervorrufen. Es wird angenommen, dass der obere Atemtrakt hauptsächlich durch sekretorisches IgA geschützt ist, während die unteren Atemwege hauptsächlich durch IgGs gesichert werden. Impfstoffe, die in den Muskel (intramuskulär) oder in die Haut (intradermal) gespritzt werden, so muss man erwarten, induzieren hauptsächlich IgG und kein sekretorisches IgA. Es ist daher möglich, dass die meisten Impfstoffe, die derzeit eine krankheitsvorbeugende oder krankheitsabschwächende Immunität induzieren, keine sterilisierende Immunität vermitteln was bedeutet, dass geimpfte Menschen zumindest mit einer gewissen Wahrscheinlichkeit noch andere anstecken können.

Wichtig bei der aktuellen Impfstoffentwicklung war auch das beschleunigte $\mathrm{Zu}$ lassungsverfahren (siehe Abb. 1): Die traditionelle Impfstoffentwicklung kann 15 Jahre oder länger dauern, beginnend mit einer langwierigen Entdeckungsphase, in der

3 Die Schleimhaut (Mukosa) kleidet den Innenraum der Rachenhöhle im Mund und auch die Oberflächen der inneren Hohlräume von Organismen aus und dient als erste Verteidigungslinie gegen Eindringlinge. Hierzu können sekretorische Antikörper abgegeben werden, die sich gegen die Eindringlinge richten. Dies wird auch als sterilisierende Immunität bezeichnet, da die Krankheitserreger so direkt von den Oberflächen ferngehalten werden. 
Impfstoffe entworfen und explorative präklinische Experimente durchgeführt werden. Darauf folgt normalerweise eine Phase mit präklinischen Experimenten und toxikologischen Studien. Produktionsprozesse werden nur vorbereitet für den Fall, dass eine Zulassung der entsprechenden staatlichen Behörden erfolgt, aber noch nicht begonnen. Während dieses Prozesses wird ein IND-Antrag (,investigational new drug“, neuartiges Prüfpräparat) gestellt und der Impfstoff als Impfstoffkandidat tritt dann in Phase I, II und schließlich in die klinische Phase III an Patienten ein. Wenn nach Abschluss der Phase-III-Studien die vorgegebenen Endpunkte erreicht sind, wird ein Antrag auf eine Biologics Licence Application (BLA) eingereicht und von den entsprechenden Zulassungsbehörden geprüft. Bei eindeutig positiver Evaluierung kann der Impfstoff schließlich lizenziert werden. Danach erst beginnt normalerweise die großtechnische Produktion, jeder frühere Beginn würde ein immenses finanzielles Risiko für das Pharmaunternehmen mit sich bringen.

Die Entwicklung des Impfstoffs für SARS-CoV-2 folgte dagegen einem beschleunigten Zeitplan, der auch ermöglicht wurde durch gentechnologische Plattformen, fortgeschrittene Sequenzierungen und genetische Editierungsmöglichkeiten, also präzise gentechnikbasierte Veränderungen in der Sequenz der DNA- und RNA-Impfstoffe (siehe Fehse, Kap. 6). Beschleunigt werden konnte die Entwicklung auch durch Erkenntnisse aus der Entwicklung von Impfstoffen gegen MERS-CoV und das erste SARS-CoVVirus. Bestehende Herstellungsprozesse wurden übernommen und Phase I/II-Studien wurden ineinander verschachtelt gestartet. Phase-III-Studien wurden bereits nach der Zwischenanalyse der Phase I/II-Ergebnisse begonnen. Auf diese Art und Weise begleitet und genehmigt von den Zulassungsbehörden wurden mehrere klinische Studienphasen parallel durchgeführt - es wurde aber keine Zulassungsphase übersprungen oder mit kleineren Kohortenzahlen gearbeitet als bei der Zulassung anderer Impfstoffe. In der Zwischenzeit hatten die Impfstoffhersteller, oft unter Verwendung staatlicher Zuschüsse, die großtechnische Produktion von mehreren Impfstoffkandidaten begonnen, auch hierbei wurden gentechnologische Produktionsverfahren im industriellen Maßstab eingesetzt. 
Abbildung 1: Traditionelle und beschleunigte Impfstoffentwicklungsphasen

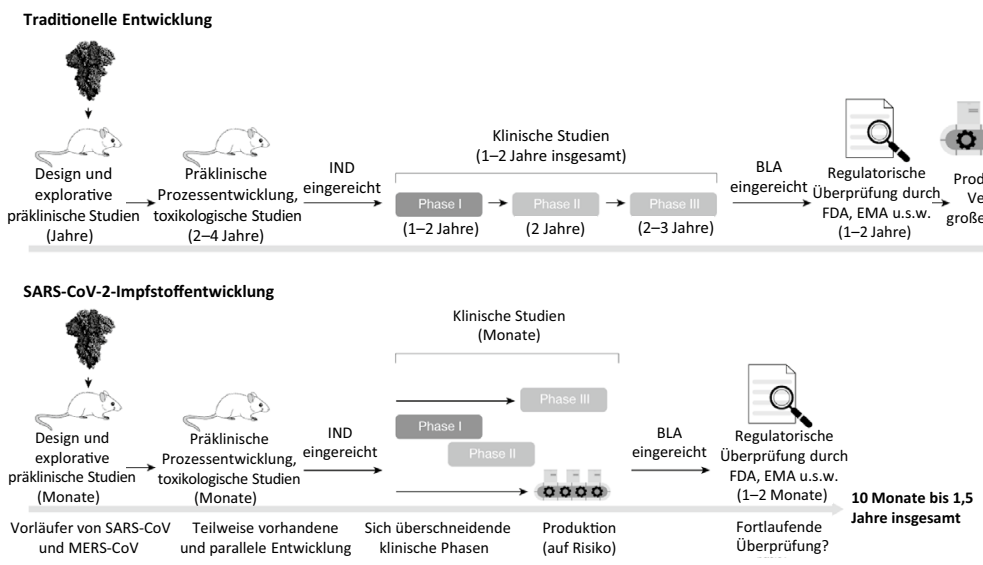

Die traditionelle Impfstoffentwicklung kann 15 Jahre oder länger dauern und beginnt mit einer langwierigen Entdeckungsphase, in der Impfstoffe entworfen und explorative präklinische Experimente durchgeführt werden. Daran schlieBen sich in der Regel formale präklinische Experimente und toxikologische Studien an. Während dieses Prozesses wird ein IND-Antrag (Investigational New Drug) gestellt und der Impfstoffkandidat tritt in die Phase I, II und III ein. Wenn nach Abschluss der Phase-III-Studien die vorgegebenen Endpunkte erreicht sind, wird ein Antrag auf Zulassung als biologisches Arzneimittel (BLA) gestellt. Dieser wird von den Zulassungsbehörden geprüft und der Impfstoff wird schließlich lizenziert. Danach beginnt die großtechnische Produktion. Die Impfstoffentwicklung für SARS-CoV-2 folgt einem beschleunigten Zeitplan. Aufgrund der Erkenntnisse aus der ersten Entwicklung von Impfstoffen gegen SARS-CoV und MERS-CoV wurde die Entdeckungsphase ausgelassen. Bestehende Prozesse wurden übernommen und Phase I/II-Studien gestartet. Nach der Zwischenanalyse der Phase I/II-Ergebnisse wurden bereits Phase-III-Studien initiiert. Dadurch liefen mehrere klinische Studienphasen parallel. In der Zwischenzeit haben Impfstoffhersteller mit der großtechnischen Produktion mehrerer Impfstoffkandidaten (auf Risiko) begonnen. Der genaue Weg, auf dem diese Impfstoffkandidaten zugelassen werden - z. B. durch eine erste Notfallzulassung - ist noch nicht klar.

\subsection{Impfstoffentwicklung mit gentechnologischen Verfahren}

Zu Beginn dieses Abschnitts über die Rolle gentechnologischer Verfahren bei der Impfstoffentwicklung ist eine Klarstellung darüber erforderlich, was Gentechnik als Hochtechnologie beinhaltet und was nicht. Gentechnik ist eine Methode, mit der die DNA, das Erbgut eines Organismus oder, wie in diesem Fall, eines Impfproduktes, verändert wird. Die Gentechnik wird wie folgt vom Bundesministerium für Ernährung und Landwirtschaft (BMEL) definiert: „Dabei kann zum Beispiel das Erbgut des Organismus neu kombiniert oder Teile des Erbguts des Organismus neu kombiniert oder Teile des Erb- 
guts eines anderen Organismus übertragen werden". ${ }^{4}$ Bei Lebend- und Totimpfstoffen werden dem Körper abgeschwächte Erreger (z. B. Viren) oder Erreger-Antigene zugeführt, hierbei sind keine gentechnologischen Verfahren notwendig. Bei genbasierten Impfstoffen stellen menschliche Körperzellen selbst ein Protein, Antigen genannt, her, nachdem das entsprechende Gen über einen Impfstoff zugeführt wurde. Diesem Prinzip folgen vektorbasierte RNA- und DNA-Impfstoffe, die unten weiter erläutert werden. Die Verfahren, um diese Impfstoffe herzustellen, beruhen auf gentechnologischen Methoden, sie führen aber im Menschen nicht zu einer Veränderung der DNA. Die gentechnologische Anwendung liegt also in der Produktion der Impfstoffe, nicht bei der Anwendung des Impfstoffes beim Menschen. Hier ist demnach der Prozess der gentechnologischen Herstellung zu unterscheiden von der Anwendung - ähnlich wie bei Insulin, das gentechnologisch hergestellt wird, wobei das Spritzen selbst bei Diabetikern kein gentechnologisches Verfahren ist, genauso wenig wie das Impfen eines vektorbasierten Impfstoffes oder eines mRNA-basierten.

Mehr als 250 Impfstoffkandidaten gegen SARS-CoV-2, basierend auf mehreren verschiedenen Plattformen, wurden allein in den ersten 12 Monaten nach dem Ausbruch in Wuhan angemeldet, wie Daten der WHO belegen (Krammer, 2020). Die WHO unterhält ein laufend aktualisiertes Arbeitsdokument, ${ }^{5}$ dass die meisten der in der Entwicklung befindlichen Impfstoffe auflistet und angibt, wie weit die Verfahren in der klinischen Erprobung oder Zulassung bereits sind. Die Impfstoffentwicklungen selbst können unterteilt werden in „traditionelle Ansätze“ (inaktivierte oder LebendvirusImpfstoffe), Impfstoffentwicklungskonzepte, die lizenzierte Impfstoffe verwenden (rekombinante Proteinimpfstoffe und vektorielle Impfstoffe), und solche, die erst noch zu einem lizenzierten Impfstoff führen müssen.

Auch die Entwicklung von mehreren Tiermodellen für SARS-CoV-2 war notwendig, darunter Mäuse, die humanes ACE2 (den oben beschriebenen Rezeptor, an den die Viren binden) exprimieren. Dies kann durch verschiedene Methoden geschehen, etwa durch Adenovirus-Transduktion oder durch andere gentechnische Verfahren, die das humane ACE2-Gen in das Mausgenom einbringen, sogenannte Knock-In-Mäuse (Dinnon et al., 2020; Gu et al., 2020). Entwickelt wurden daneben auch Mausmodelle mit mausadaptierten SARS-CoV-2-Stämmen sowie Frettchen-, Hamster- und NHP-Modelle, hier insbesondere Rhesusmakaken (Deng et al., 2020; Yu et al., 2020). Das Hamstermodell kann eine schwere Erkrankung imitieren, wie sie bei einem Teil der infizierten Menschen

4 Siehe unter: https://www.bmel.de/DE/themen/landwirtschaft/gruene-gentechnik/gentechnikwasgenauistdas-definition.html [20.04.2021].

5 Siehe unter: https://www.who.int/publications/m/item/draft-landscape-of-covid-19-candidatevaccines [20.04.2021]. 
auftritt, während das NHP-Modell eine leichte bis mittelschwere Infektion widerspiegelt. Für Impfstoffe, die in klinischen Studien bereits weit fortgeschritten sind, gibt es nur begrenzte Daten in Hamstermodellen, aber viele der Impfstoffkandidaten wurden in NHPs getestet, was einen direkteren Vergleich zwischen ihnen ermöglicht.

Die Vergleiche zwischen den Impfstoffen in der klinischen Erprobung müssen jedoch mit Vorsicht interpretiert werden, da die Impfdosen und Verabreichungswege variieren, ebenso wie die Impfschemata und -zeitpläne. Wichtig ist, dass, obwohl alle Studien Neutralisierungsdaten verwenden (d. h., dass es nachweisbare Antikörper gegen das Spike-Protein gibt), die Unterschiede in den Analysewegen zu großen Verzerrungen in den Erfolgsmeldungen für die Vakzine führen können. Darüber hinaus wurde in den meisten Studien der Gehalt an infektiösen Viren in den oberen und unteren Atemwegen nicht bestimmt, was bedeutsam zu wissen wäre, um zu beurteilen, ob die geimpften Personen selbst noch infektiös sind. Krammer hat diese Entwicklungen in einem Übersichtsartikel zusammengefasst (Krammer, 2020).

Hier nun eine Beschreibung der verschiedenen Impfstoffe, die für SARS-CoV-2 entwickelt wurden oder sich in der Entwicklung befinden (Stand 05/2021).

\subsubsection{RNA-Impfstoffe}

RNA-Impfstoffe (siehe Abb. 2l) sind die neueste Variante von Impfstoffen, werden hier aber zuerst beschrieben, da der RNA-Impfstoff von BioNTech-Pfizer (BNT162b2, Comirnaty) in den USA, Großbritannien und Europa der erste zugelassene Impfstoff gegen SARS-CoV-2 war, direkt gefolgt von einem zweiten, mRNA-basierten Impfstoff von Moderna (mRNA-1273, COVID-19 Vaccine Moderna). Auch diese RNA-Impfstoffe wurden mit gentechnologischen Verfahren hergestellt, denn sie enthalten genetische Informationen des SARS-CoV-2-Virus. Als Vorlage für den mRNA-Impfstoff wird ein DNA-Stück am Computer entworfen. Mithilfe dieser elektronischen Sequenz wird ein DNA-Stück synthetisiert. Dieses enthält den Bauplan des Sars-CoV-2-Spike-Proteins (siehe Abb. 2b), eines wichtigen Bestandteils der Hülle des Coronavirus (siehe Abb. 2a). Hier wird nicht der gesamte Bauplan des Spike-Proteins verwendet, sondern vor allem die virale ACE2Rezeptorbindungsdomäne (RBD), also der Bereich des Proteins, der an den ACE2-Rezeptor bindet. Um den Impfstoff richtig zu ,programmieren“, wird anschließend im Labor mithilfe von Bakterien die DNA für das Spike-Protein in Bioreaktoren gentechnologisch synthetisiert. Das Spike-Protein eignet sich besonders gut für eine Impfung, da es für das Andocken an die Zellen verantwortlich ist, weswegen sie an der Außenseite des Virus liegen und dadurch für das Immunsystem einen guten Angriffspunkt bilden. Die in großen Mengen synthetisierte DNA des Spike-Proteins dient als Vorlage, um im gro- 
ßen Stil richtig programmierte mRNA zu produzieren. Dieses gentechnologische Verfahren läuft folgendermaßen ab: Das DNA-Stück des Spike-Proteins wird in Ringform (Plasmid) in Bakterien eingeschleust, die dann in großen Mengen vermehrt werden. Die Hülle der Bakterien wird zerstört und die vervielfältigten Plasmide werden isoliert und gereinigt. Der DNA-Strang wird wie ein Reißverschluss aufgetrennt. Mithilfe des Enzyms RNA-Polymerase wird mit dem DNA-Bauplan als Vorlage die mRNA hergestellt. Die mRNA wird im Anschluss erneut aufgereinigt. Zusätzlich wird die RNA stabilisiert, wofür einzelne Basen gegen stabilere Varianten ausgetauscht werden - ohne die Struktur des finalen Spike-Proteins, das aus der RNA abgelesen wird, an Ribosomen ${ }^{6} \mathrm{zu}$ verändern. Die reine mRNA wird als letzter Verfahrensschritt in winzige Lipidnanopartikel (LNPs, siehe Abb. 2l) verpackt. So wird die mRNA nicht so schnell vom Körper abgebaut und der Bauplan des Virus-Hüllproteins gelangt leichter ins Zellinnere. Die verpackte mRNA wird in eine Flüssigkeit gegeben und in spezielle Glasampullen gefüllt. In Deutschland prüft das staatliche Paul-Ehrlich-Institut (PEI) in Langen Stichproben und überwacht die Produktionsstätten.

Die entscheidende neue Eigenschaft des BioNTech-Impfstoffs ist die Verpackung der mRNA, ihre Schutzschicht aus besonderen Lipidmolekülen. Die winzigen Teilchen müssen genau die richtige Größe besitzen, damit sie den Weg in die menschliche Zelle finden. Doch diese Zutat erhält Pfizer/BioNTech von Zulieferern wie etwa der österreichischen Firma Polymun. Falls diese Firmen an ihre Kapazitätsgrenzen stoßen, kann sich die Produktion wieder verzögern. Jeder Produktionsschritt muss zudem vom PEI freigegeben werden. In der Regel dauert die Chargenprüfung bei Impfstoffen nur wenige Tage. Dafür muss der Stoff einen bestimmten Toleranzbereich in der Reinheit und der Genauigkeit einhalten, was der Hersteller penibel überwachen muss, um seine Lizenz nicht zu gefährden. Später, wenn ein Hersteller sehr viel Erfahrung in den Produktionsabläufen hat und eine valide Qualitätssicherung vorweisen kann, kann er eine Befreiung von der Chargenfreigabe beantragen.

Ähnlich wie bei DNA-Impfstoffen (siehe 18.2.5) liefern daher auch RNA-Impfstoffe die genetische Information für das Antigen, und das Antigen wird dann in den Körperzellen des geimpften Individuums produziert. Es kann bei diesem Verfahren prinzipiell eine mRNA (mit Modifikationen) oder eine selbstreplizierende ${ }^{7}$ RNA verwendet

6 Ribosomen sind die Komplexe in der Zelle, die Proteine anhand der mRNA-Bauanleitung synthetisieren.

7 Selbstreplizierende RNA enthält nicht nur die Information für das Antigen (hier das Spike-Protein), sondern auch für weitere Proteine, die die Vervielfältigung der RNA in der Zelle ermöglichen. Für einen solchen Impfstoff gibt es im Moment noch keine Zulassung (Stand 05/2021). 
werden. Die RNA wird üblicherweise über Lipid-Nanopartikel (LNPs, siehe oben) verabreicht.

Tatsächlich ist bis zur Zulassung der mRNA-Impfstoffe von BioNTech und Moderna zuvor noch nie ein mRNA-Impfstoff zugelassen worden. Eine Frage, die in diesem Zusammenhang vor allem von Laien diskutiert wurde, war, ob mRNA-Impfstoffe eine genetische Veränderung beim Menschen bewirken können. Der Umstand, dass RNAImpfstoffe durch gentechnische Verfahren hergestellt werden, bedeutet jedoch nicht, dass sie eine "Genmanipulation“ bewirken oder die menschliche DNA verändern. Hier muss man sich klarmachen, was eine RNA/mRNA ist. Wie oben beschrieben, handelt es sich um eine relativ instabile Nukleinsäure, die aus dem Kern in den Rest der Zelle wandert, dort der Proteinbiosynthese dient und danach von den Zellen abgebaut wird. Sie wandert nicht zurück in den Zellkern, sodass auch die RNA des Impfstoffes nicht in den Kern der menschlichen Zelle eindringen kann, um dort das Genom zu verändern.

RNA-Impfstoffe wurden schon in den letzten Jahren als sehr vielversprechend bezeichnet und tatsächlich befanden sich schon vor der Corona-Pandemie einige RNAImpfstoffe in der Entwicklung, z. B. gegen das Zika-Virus oder das Cytomegalovirus. Die ersten RNA-Impfstoffe, die je zugelassen wurden, waren aber die von BioNTech/Pfizer und anschließend Moderna, jeweils zuerst von der amerikanischen FDA (Food and Drug Administration; im Dezember 2020). CureVac und Arcturus haben Kandidaten in Phase II/III-Studien, und ein Impfstoffkandidat des Imperial College London und der chinesischen Befreiungsarmee befindet sich ebenfalls in der Entwicklung (Stand 05/2021). Vorteile dieser Technologie sind, dass der Impfstoff vollständig in vitro, also in Kultursystemen hergestellt werden kann, ohne dass man mit dem SARS-CoV-2-Virus direkt arbeiten muss. Unsicherheiten bestanden bei dieser Technologie auch dahingehend, welche Probleme in Bezug auf die Produktion in großem Maßstab und die langfristige Lagerstabilität auftreten würden, da eine Tiefkühllagerung $\left(-70^{\circ} \mathrm{C}\right)$ erforderlich ist. Darüber hinaus werden diese Impfstoffe durch Injektion in Muskelgewebe verabreicht und induzieren daher wahrscheinlich keine starke Schleimhautimmunität, die durch eine andere Antikörperklasse, die IgA-Antikörper, vermittelt werden. Unklar ist also, in welchem Ausmaß das Virus die Geimpften nicht nur vor schweren Erkrankungen schützt, sondern inwiefern diese geimpften Personen das Virus auch nicht mehr weitergeben, sprich noch andere anstecken können. 
Abbildung 2: Graphische Darstellung der Impfstofftypen

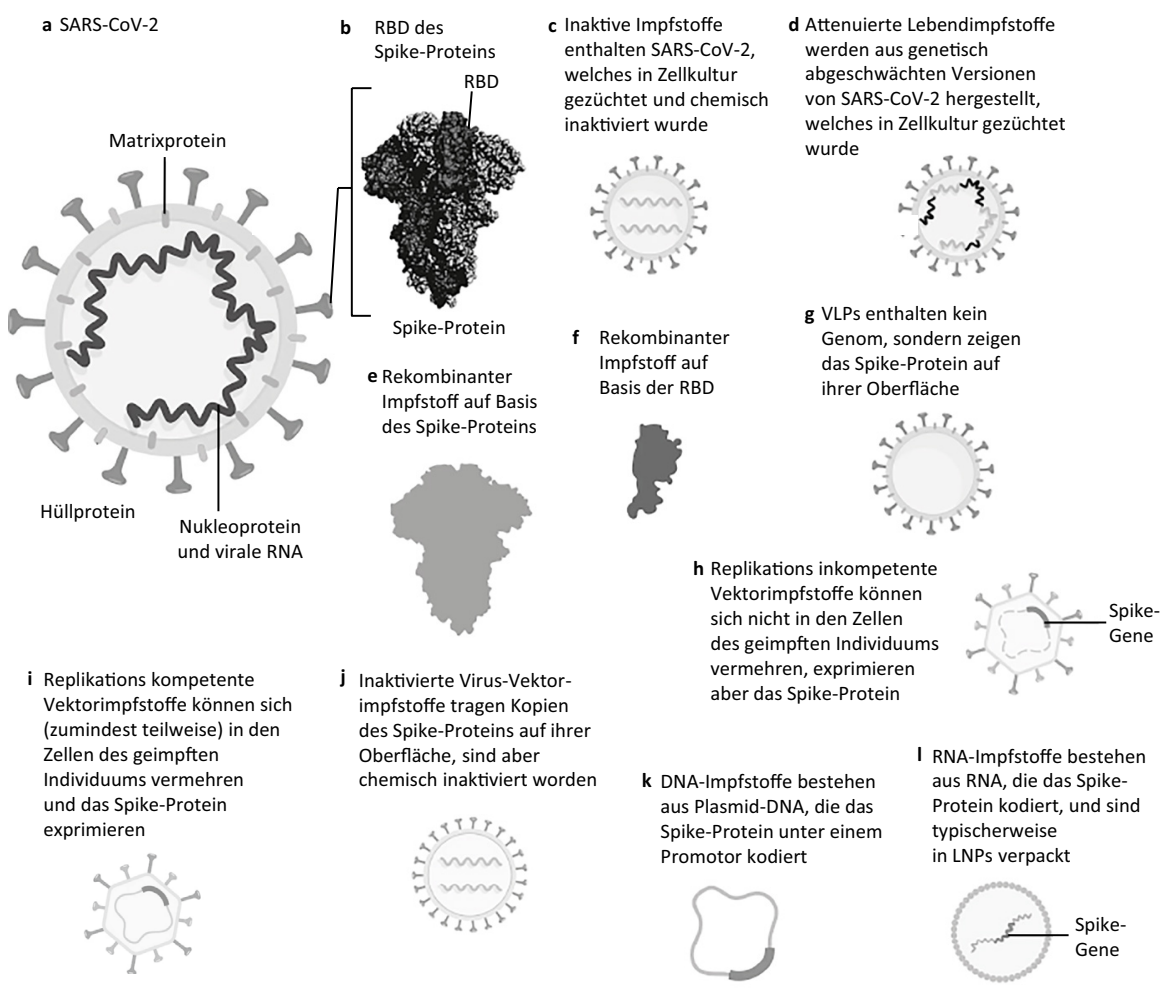

Impfstoffplattformen, die für die Entwicklung des SARS-CoV-2-Impfstoffs verwendet werden (nach Kramer, 2020):

a: Eine schematische Darstellung der Strukturproteine des SARS-CoV-2-Virus, einschließlich der Lipidmembran (der Schicht, die Außenseite und Innenraum des Virus trennt und in die Matrixproteine eingebettet sind), der innerhalb der Hülle liegenden viralen RNA im Verbund mit Nukleoproteinen sowie der an der Außenseite der Membran liegenden Hüllproteine und Spike-Proteine.

b: Die Struktur des Spike-Proteins; ein Monomer (also ein einzeln vorliegendes Protein) ist dunkelgrau hervorgehoben und die Rezeptorbindungsdomäne (RBD) ist hellgrau dargestellt.

c-I: Aktuelle SARS-CoV-2-Impfstoffkandidaten umfassen inaktivierte Virusimpfstoffe (c), abgeschwächte (attenuierte) Lebendimpfstoffe (d), rekombinante Proteinimpfstoffe auf der Basis des Spike-Proteins (e), der RBD (f) oder auf virusähnlichen Partikeln (g), replikationsinkompetente Vektorimpfstoffe (h), replikationskompetente Vektorimpfstoffe (i), 
inaktivierte Virus-Vektor-Impfstoffe, die das Spike-Protein auf ihrer Oberfläche aufweisen (j), DNA-Impfstoffe (k) und RNA-Impfstoffe (I).

\subsubsection{Vektorbasierte Impfstoffe}

Neben den mRNA-Impfstoffen waren auch replikationsinkompetente Vektoren, die sich nicht in den Zellen des geimpften Individuums vermehren können, sehr schnell und erfolgreich in der Entwicklung von SARS-CoV-2-Impfstoffen (siehe Abb. 2h). Replikationsinkompetente Vektoren stellen eine große Gruppe von Impfstoffen dar und basieren typischerweise auf einem anderen Virus, das so verändert wurde, dass es das gewünschte Antigen, hier das Spike-Protein, exprimiert und durch das Löschen von Teilen des ursprünglichen Virengenoms an der Replikation in vivo gehindert wird. Die meisten dieser Ansätze basieren auf Adenovirus (AdV)-Vektoren, wobei auch modifizierte Vaccinia Ankara (MVA), humane Parainfluenzavirus-Vektoren, Influenzavirus, Adeno-assoziiertes Virus und Sendai-Virus Anwendung gefunden haben. ${ }^{8}$ Die Mehrzahl dieser Vektoren wird intramuskulär gespritzt, gelangen so in die Muskelzellen des geimpften Individuums und exprimieren das gewünschte Antigen, auf das dann das Immunsystem des geimpften Menschen reagiert.

Dieser Ansatz hat eine Reihe von Vorteilen. So ist es nicht notwendig, während der Produktion mit lebendem SARS-CoV-2 zu hantieren, es gibt beträchtliche Erfahrung mit der Produktion größerer Mengen einiger dieser Vektoren (ein Ad26-MVA-basierter Impfstoff gegen das Ebola-Virus wurde kürzlich in der Europäischen Union zugelassen) und die Vektoren zeigen eine gute Stimulation sowohl der B-Zell- als auch der T-ZellAntwort. Ein Nachteil ist, dass einige dieser Vektoren durch bereits vorhandene Vektorimmunität neutralisiert werden. Dies wird umgangen durch die Verwendung von Vektortypen, die entweder beim Menschen selten sind oder von Tierviren abgeleitet sind, oder durch die Verwendung von Viren, die von sich aus wenig Immunität induzieren (z. B. Adeno-assoziierte Viren, sogenannte AAVs).

Darüber hinaus kann es trotzdem zu einer Vektorimmunität kommen durch das Impfschema einer Doppelimpfung selbst. Denn die meisten dieser Impfungen funktionieren nach dem Prime-Boost-Regime, es erfolgt also nach einer initialen (,prime“) Impfung eine zweite, die die Immunantwort nachhaltig stimulieren soll („,boost“). Nun kann es aber bei der 2. Impfung zu einer Reaktion auf das Vektorvirus kommen, was die Produktion des gewünschten Antigens deutlich vermindern kann. Dies versucht man teilweise zu umgehen, indem man zwei verschiedene Virus-Vektoren verwendet, einen zum Primen und einen zum Boosten bei der 2. Impfung.

8 Für eine Übersicht und die darin zitierte Literatur siehe Krammer (2020). 
Mehrere replikationsinkompetente Vektor-Impfstoffkandidaten gegen SARS-CoV-2 sind mittlerweile zugelassen: ChAdOx1 nCoV-19 (von AstraZeneca/Oxford basierend auf einem Schimpansen-AdV), von Janssen/Johnson\&Johnson (unter Verwendung eines AdV26-basierten Vektors) und von CanSino (AdV5). Andere vektorbasierte Impfstoffe befinden sich noch in der klinischen Testphase (Stand 05/2021).

Darüber hinaus gibt es noch replikationskompetente Vektoren (siehe Abb. 2i). Diese stammen typischerweise von abgeschwächten Viren oder viralen Impfstämmen, die so manipuliert wurden, dass sie ein Transgen exprimieren, in diesem Fall das Spike-Protein. In einigen Fällen werden Tierviren verwendet, die sich nicht besonders effizient replizieren und beim Menschen keine Krankheit verursachen. Dieser Ansatz kann zu einer robusteren Induktion einer Immunität führen, da sich der Vektor in gewissem Umfang im geimpften Individuum vermehrt und oft auch eine starke angeborene Immunantwort auslöst. Einige dieser Vektoren können auch über Schleimhautoberflächen verabreicht werden, was mukosale (die Schleimhaut betreffende) Immunantworten auslösen kann. Dies würde auch die Übertragung der Infektion des geimpften Menschen auf andere Menschen unterbinden, da hier eine gute Chance besteht, dass die IgA-Produktion gegen das Spike-Protein im Nasen-Rachen-Raum angeregt wird.

Derzeit befinden sich nur zwei replikationskompetente Vektoren in Phase I/II der klinischen Erprobung gegen SARS-CoV-2: ein gentechnisch veränderter Masern-Impfstamm, der vom Institut Pasteur und Themis (jetzt von Merck übernommen) entwickelt wurde, und ein Vektor auf Basis des Influenzavirus, der von Beijing Wantai Biological Pharmacy entwickelt wird. Des Weiteren sind einige andere replikationskompetente Vektoren in der Erprobung zum Zeitpunkt des Schreibens dieses Übersichtsartikels, einschließlich Vektoren, die auf dem Vesikulären-Stomatitis-Virus (VSV), den Pferdepocken und dem Newcastle Disease Virus (NDV) beruhen, aber keinen Schaden mehr anrichten können, da sie sich nicht mehr vermehren können. Vektoren auf Basis von NDV sind von Interesse, da dieses Virus in Eiern zu hohen Mengen heranwächst und die Vektoren mithilfe der globalen Herstellungsinfrastruktur zum Influenzavirus produziert werden könnten, die auf gleiche Art und Weise produziert werden. Im Gegensatz zu Masern und den VSV-Vektoren sind sie wahrscheinlich sicher genug, um intranasal verabreicht zu werden, was zu einer Schleimhautimmunität führen und damit zukünftig eine attraktive Impfergänzung sein könnte, da es sowohl die Geimpften als auch Kontaktpersonen der Geimpften schützen würde. 


\subsubsection{Rekombinante proteinbasierte Impfstoffe}

Rekombinante Proteinimpfstoffe können unterteilt werden in rekombinante SpikeProtein-basierte Impfstoffe (siehe Abb. 2e), rekombinante RBD-basierte Impfstoffe (siehe Abb. 2f) und Impfstoffe auf Basis von virusähnlichen Partikeln (VLP) (siehe Abb. 2g). Diese rekombinanten Proteine können in verschiedenen Expressionssystemen exprimiert werden, einschließlich Insektenzellen, Säugetierzellen sowie Hefe und Pflanzen, und es ist wahrscheinlich, dass RBD-basierte Impfstoffe auch in Kolibakterien (Escherichia coli) exprimiert werden können. Die Ausbeuten sowie die Art und das Ausmaß der posttranslationalen Modifikationen ${ }^{9}$ variieren je nach Expressionssystem, bieten aber eine sehr gute Variabilität schneller Anpassungen an Virusvarianten. Für rekombinante Spike-Protein-basierte Impfstoffe sprechen insbesondere Modifikationen wie die Deletion der polybasischen Spaltstelle, ${ }^{10}$ der Einbau von zwei (oder mehr) stabilisierenden Mutationen sowie die Art der Aufreinigung (lösliches Protein versus Membranextraktion). Mit diesen gentechnologischen Verfahren kann schnell und effizient die hervorgerufene Immunantwort beeinflusst werden. Ein weiterer Vorteil dieser Impfstoffplattformen ist, dass sie ohne den Umgang mit lebenden Viren hergestellt werden können. Darüber hinaus sind einige rekombinante Proteinimpfstoffe - wie der FluBlokImpfstoff gegen Influenza - lizenziert worden, und es gibt beträchtliche Erfahrung mit ihrer Herstellung.

Allerdings haben solche Impfstoffe auch spezifische Nachteile. Das Spike-Protein ist relativ schwer zu exprimieren, was sich wahrscheinlich auf die Produktionsausbeute und die Anzahl der Dosen auswirkt, die produziert werden können. Die RBD, also die Bindestelle, ist einfacher zu exprimieren. Allerdings ist es ein relativ kleines Protein, wenn es allein exprimiert wird, und obwohl starke neutralisierende Antikörper an die RBD binden, fehlen ihr andere neutralisierende Epitope, ${ }^{11}$ die auf dem Spike-Protein in voller Länge vorhanden sind. Dies könnte RBD-basierte Impfstoffe anfälliger für Auswirkungen von Antigendrift (die Veränderung von Antigenen der Viren, die etwa durch Mutationen im Virusgenom entstehen können) machen, wie sie in Virusvarianten schon beobachtet wurden, als Impfstoffe, die das Spike-Protein in voller Länge ent-

9 Posttranslationale Modifikationen sind Änderungen an den Proteinen, die nach ihrer Synthese (der Translation) in der Zelle vorgenommen werden, etwa das Anhängen von Zuckerketten, Fetten oder eine bestimmte Faltung. Solche Veränderungen ändern die Eigenschaften der Proteine. Es ist daher bei der Wahl des Expressionssystems wichtig, nicht nur das Protein selbst, sondern möglichst auch die posttranslationalen Modifikationen nachzubilden.

10 Die polybasische Spaltstelle ist eine positiv geladene Stelle nahe der eigentlichen Bindungsstelle des Spike-Proteins, die eine starke Bindung des Virus an den negativ geladenen menschlichen Rezeptor ermöglicht. Blockiert man diese Stelle, wird die Bindung des Virus an die Zelle geschwächt.

11 Epitope sind die Abschnitte eines Antigens, die von den Antikörpern erkannt werden. 
halten. Viele rekombinante Protein-Impfstoffkandidaten gegen SARS-CoV-2 befinden sich derzeit in der präklinischen Entwicklung, und mehrere Impfstoffe auf Spike-Protein- und RBD-Basis werden bereits in klinischen Studien erprobt (FDA, 2020). ${ }^{12}$ Für diese Impfstoffe wurden Daten von NHPs und aus Phase-I-Studien für Novavax (Keech et al., 2021) erhoben. VLP-basierte Impfstoffkandidaten, einschließlich eines von Medicago produzierten, sind ebenfalls in der klinischen Erprobung. Ähnlich wie bei inaktivierten Impfstoffen werden diese Kandidaten typischerweise injiziert und es wird nicht erwartet, eine robuste Schleimhautimmunität zu erreichen.

Diese proteinbasierten Impfstoffplattformen werden auch als Nanopartikeltechnologie bezeichnet. Am schnellsten war der Impfstoff Novavax erfolgreich (Tian et al., 2021), der auch in einer Phase-III-Studie erfolgreich getestet wurde. So hat die Analyse der Ergebnisse aus der randomisierten, beobachterblinden, placebokontrollierten Phase-III-Studie mit NVX-CoV2373 eine Effektivität von 96 \% gegen schwere Verläufe der Covid-19-Erkrankung nachweisen können. Dieser Impfstoffkandidat verwendet eine rekombinante Version des Spike-Proteins in voller Länge (siehe Abb. 2e), bei dem die polybasische Spaltstelle entfernt wurde und zwei stabilisierende Prolinreste (bestimmte Aminosäuren) vorhanden sind. Es wird in Insektenzellen exprimiert und durch Membranextraktion aufgereinigt. Das Spike-Protein zeigt Rosettenbildung über seine hydrophoben Schwänze ${ }^{13}$ und vergrößert so die Oberfläche, die dann für Antikörper zugänglich ist und wie im Falle von Novavax als „Nanopartikel“ verabreicht werden können. Das Antigen wurde mit oder ohne den die Wirkung verstärkenden Hilfsstoff (Adjuvans) Matrix-M verwendet und in einem Prime-Boost-Schema mit einem dreiwöchigen Intervall verabreicht (siehe Tab. 1). Örtlich begrenzte heftige Immunreaktionen (lokale Reaktogenität) und den ganzen Körper betreffende Reaktionen waren nach der ersten Dosis milder als nach der zweiten Dosis und wurden hauptsächlich durch das Adjuvans verursacht. Unwohlsein, Müdigkeit und Kopfschmerzen waren die häufigsten systemischen Nebenwirkungen, Fieber war jedoch selten.

\subsubsection{Inaktivierte Virusvektoren}

Einige Impfstoffe gegen SARS-CoV-2 basieren auf viralen Vektoren, die das Spike-Protein auf ihrer Oberfläche tragen, dann aber vor der Verwendung inaktiviert werden

12 Development and Licensure of Vaccines to Prevent COVID-19. Siehe unter: https://www.fda.gov/ media/139638/download [20.04.2021].

13 Die hydrophoben (Wasser meidenden und Fett liebenden) Schwänze sind Bestandteile bestimmter Aminosäuren des Proteins und lagern sich zusammen, um möglichst wenig Kontakt zu Wasser zu haben. Dadurch kommt es zur Rosettenbildung, also zur Clusterbildung der Proteine. 
(als erstes gelang dies Wang et al., 2020) (siehe Abb. 2j). Der Vorteil dieser Impfstoffe ist, dass der Inaktivierungsprozess die Vektoren sicherer macht, da sie sich nicht replizieren können, selbst in einem immungeschwächten Menschen. Ein Nachteil ist, dass bei der Verwendung von standardmäßigen viralen Vektoren die Menge des Antigens, die dem Immunsystem präsentiert wird, nicht einfach kontrolliert werden kann. Genau dies gelingt bei Impfstoffen sehr gut, die aus inaktivierten oder rekombinanten Proteinimpfstoffen bestehen. Beispiele für inaktivierte Virusvektoren sind NDV-basierte Impfstoffe, die das Spike-Protein auf ihrer Oberfläche tragen und ähnlich wie Influenza-Virusimpfstoffe hergestellt werden können, sowie Tollwut-Vektoren.

\subsubsection{DNA-Impfstoffe}

DNA-Impfstoffe (siehe Abb. 2k) basieren auf Plasmid-DNA (also ringförmige und sich autonom vermehrende DNA-Moleküle), die in großem Maßstab in Bakterien gentechnologisch produziert werden kann. Typischerweise enthalten diese Plasmide Säugetier-Expressionspromotoren und das Gen, das für das Spike-Protein kodiert und nach der Verabreichung im geimpften Individuum exprimiert wird. Der große Vorteil dieser Technologien ist die Möglichkeit der großtechnischen Produktion in Kolibakterien sowie die hohe Stabilität der Plasmid-DNA, die im Unterschied zur RNA doppelsträngig ist. Allerdings zeigen DNA-Impfstoffe oft eine geringe Immunogenität, also eine geringere Fähigkeit, eine Reaktion des Immunsystems hervorzurufen, und müssen über entsprechende Geräte verabreicht werden, um effizient zu sein. Diese Anforderung an Verabreichungshilfen, wie z. B. Elektroporatoren, schränkt ihre Verwendung ein.

\subsection{Fazit}

Insgesamt kann man festhalten, dass innerhalb von nur zwölf Monaten (02/2020 bis 02/2021) vier Impfstoffe gegen SARS-CoV-2 in Europa, USA und GB zugelassen wurden, davon zwei mRNA-Impfstoffe und zwei vektorbasierte Impfstoffe. Dies wäre ohne sichere und effiziente gentechnologische Verfahren nicht möglich gewesen. Hinzu kommen noch SputnikV aus Russland und zwei Impfstoffe aus China, die derzeit noch keine Zulassung in Deutschland haben (Stand 05/2021), aber weltweit schon in verschiedenen Ländern eingesetzt werden. Weitere Impfstoffe werden dazu kommen und werden auch notwendig sein, denn es ist eine riesige logistische und gentechnologische Herausforderung, geschätzte 12 Milliarden Impfdosen herzustellen und über die gesamte Welt zu verteilen. Parallel müssen noch Impfplattformen entwickelt werden, die sich laufend an mutierte Virusvarianten anpassen können, was auch zulassungstechnisch eine gro- 
ße Herausforderung sein wird. Zu erwarten ist, dass im Jahr 2022 eine weitere Impfung gegen Virusvarianten erfolgen muss. Völlig offen ist die Frage, welche Akzeptanz die Impfstoffe in der Bevölkerung verschiedener Länder erreichen werden und ob die Weltgemeinschaft es schafft, die Impfstoffe auch fair zu verteilen - und hier spielen nicht nur Fragen der Handhabung und Logistik eine Rolle. Die gentechnologisch getriebene Wissenschaft hat geliefert, nun sind politische Mechanismen gefragt, eine effiziente und faire Verteilung zu gewährleisten.

Tabelle 1: Zugelassene Impfstoffe und einige Impfstoffkandidaten (Stand 05/2021) zur besseren Übersicht der im Text genannten Impfstoffe

\begin{tabular}{|c|c|}
\hline $\begin{array}{c}\text { Unternehmen } \\
\text { (Referenz) }\end{array}$ & Impfstoff (Typ) \\
\hline $\begin{array}{c}\text { BioNTech/Pfizer } \\
\text { (Walsh et al., 2020) }\end{array}$ & BNT162b2 (mRNA expressing spike protein) \\
\hline $\begin{array}{c}\text { Moderna } \\
\text { (Jackson et al., 2020) }\end{array}$ & mRNA-1273 (mRNA expressing spike protein) \\
\hline $\begin{array}{c}\text { AstraZeneca/Oxford } \\
\text { (Folegatti et al., 2020) }\end{array}$ & $\begin{array}{c}\text { ChAdOx1 nCoV-19 } \\
\text { (non-replicating chimpanzee AdV expressing spike protein) }\end{array}$ \\
\hline $\begin{array}{c}\text { Novavax } \\
\text { (Keech et al., 2021) }\end{array}$ & $\begin{array}{c}\text { NVX CoV2373 (Matrix-M) } \\
\text { spike protein ,rosettes' }\end{array}$ \\
\hline $\begin{array}{c}\text { CanSino } \\
\text { (Zhu et al., 2020) }\end{array}$ & $\begin{array}{c}\text { Ad5 nCoV (non-replicating AdV5 expressing spike protein) } \\
\text { Sinovac } \\
\text { (Zhang et al., 2021) }\end{array}$ \\
\hline Sinopharm & $\begin{array}{c}\text { CoronaVac (inactivated SARS-CoV-2 + aluminium hydroxide) } \\
\text { Inactivated whole virus COVID-19 vaccine } \\
\text { (inactivated SARS-CoV-2 + aluminium hydroxide) }\end{array}$ \\
\hline
\end{tabular}

\subsection{Literaturverzeichnis}

Alsoussi, W. B. et al. (2020): A potently neutralizing antibody protects mice against SARS-CoV-2 infection. In: J. Immunol. 205: 915-922.

Amanat, F. et al. (2020): A serological assay to detect SARS-CoV-2 seroconversion in humans. In: Nat. Med. 26: 1033-1036.

Cui, J. et al. (2019): Origin and evolution of pathogenic coronaviruses. In: Nat. Rev. Microbiol. 17: 181192.

Deng, W. et al. (2020): Primary exposure to SARS-CoV-2 protects against reinfection in rhesusmacaques. In: Science 369: 818-823. 
Dinnon, K. H. et al. (2020): A mouse-adapted model of SARS-CoV-2 to test COVID-19 countermeasures. In: Nature 586: 560-566.

Folegatti, P. M. et al. (2020): Safety and immunogenicity of the ChAdOx1 nCoV-19 vaccine against SARS-CoV-2: a preliminary report of a phase $1 / 2$, single-blind, randomised controlled trial. In: Lancet 396: 467-478.

Grifoni, A. et al. (2020): Targets of T cell responses to SARS-CoV-2 coronavirus in humans with COVID-19 disease and unexposed individuals. In: Cell 181: 1489-1501.e15.

$\mathrm{Gu}, \mathrm{H}$. et al. (2020): Adaptation of SARS-CoV-2 in BALB/c mice for testing vaccine efficacy. In: Science 369(5611): 1603-1607.

Hoffmann, M. et al. (2020): SARS-CoV-2 cell entry depends on ACE2 and TMPRSS2 and is blocked by a clinically proven protease inhibitor. In: Cell 181(2): 271-280 e278.

Jackson, L. A. et al. (2020): An mRNA vaccine against SARS-CoV-2 - preliminary report. In: N Engl J Med 383: 1920-1931. DOI: 10.1056/NEJMoa2022483.

Keech, C. et al. (2021): Phase 1-2 trial of a SARS-CoV-2 recombinant spike protein nanoparticle vaccine. In: New England Journal of Medicine 383(24): 2320-2332.

Krammer, F. (2020): SARS-CoV-2 vaccines in development. In: Nature 586(7830): 516-527.

Liu, L. et al. (2020): Potent neutralizing antibodies against multiple epitopes on SARS-CoV-2 spike. In: Nature 584: 450-456.

Martin, J. E. et al. (2008): A SARS DNA vaccine induces neutralizing antibody and cellular immune responses in healthy adults in a phase I clinical trial. In: Vaccine 26: 6338-6343.

Okba, N. M. A. et al. (2020): Severe acute respiratory syndrome coronavirus 2-specific antibody responses in coronavirus disease patients. In: Emerging Infect. Dis: 26: 1478-1488.

Tian, J.-H. et al. (2021): SARS-CoV-2 spike glycoprotein vaccine candidate NVX-CoV2373 immunogenicity in baboons and protection in mice. In: Nat Commun 12(372), Online-Publikation 11.01.2021. DOI: $10.1038 / \mathrm{s} 41467-020-20653-8$.

Tortorici, M. A./Veesler, D. (2019): Structural insights into coronavirus entry. In: Adv. Virus Res. 105: 93-116.

Wajnberg, A. et al. (2020): SARS-CoV-2 infection induces robust, neutralizing antibody responses that are stable for at least three months. DOI: 10.1101/2020.07.14.20151126.

Walsh, E. E. et al. (2020): RNA-based COVID-19 vaccine BNT162b2 selected for a pivotal efficacy study. In: NEJM 383: 2439-2450. 
Wang, H. et al. (2020): Development of an inactivated vaccine candidate, BBIBP-CorV, with potent protection against SARS-CoV-2. In: Cell 182: 713-721.e9.

Xia, S. et al. (2020): Effect of an inactivated vaccine against SARS-CoV-2 on safety and immunogenicity outcomes: interim analysis of 2 randomized clinical trials. In: JAMA 324: 951-960.

Yu, J. et al. (2020): DNA vaccine protection against SARS-CoV-2 in rhesus macaques. In: Science 369: 806-811.

Zhang, Y. et al. (2021): Safety, tolerability, and immunogenicity of an inactivated SARS-CoV-2 vaccine in healthy adults aged 18-59 years: a randomised, double-blind, placebo-controlled, phase 1/2 clinical trial. In: The Lancet 2(2): 181-192.

Zhou, P. et al. (2020): A pneumonia outbreak associated with a new coronavirus of probable bat origin. In: Nature 579: 270-273.

Zhu, F. C. et al. (2020): Immunogenicity and safety of a recombinant adenovirus type-5-vectored COVID-19 vaccine in healthy adults aged 18 years or older: a randomised, double-blind, placebocontrolled, phase 2 trial. In: Lancet 396: 479-488. 